\title{
Training Needs Assessment of Training Professionals Working in Agricultural Training Institutes in Punjab, Pakistan
}

\author{
Muhammad Yaseen ${ }^{1 *}$, Syed Amir Zia Abid ${ }^{1}$, Muhammad Luqman', Syed Wasim Hasan², Muhammad \\ Aqeel Pitafi ${ }^{3}$, Muhammad Tariq Chaudhry ${ }^{4}$ and Muhammad Ameen ${ }^{5}$
}

${ }^{1}$ Department of Agricultural Extension, College of Agriculture, University of Sargodha, Pakistan; ${ }^{2}$ Department of Plant Breeding and Genetics, College of Agriculture, University of Sargodha, Pakistan; ${ }^{3}$ Barani Agricultural Training Institute, Rawalpindi, Punjab, Pakistan; ${ }^{4}$ In-service Agricultural Training Institute, Sargodha, Punjab, Pakistan; ${ }^{5}$ College of Engineering, Nanjing Agricultural University, Nanjing, China.

Abstract | Training Needs Assessment (TNA) is a systematic procedure to gather information regarding needs of employees with emphasis to gain organizational objectives. Therefore, the current study was conducted to access the training needs of training professionals working in Agricultural Training Institutes (ATIs) of Punjab. For this purpose, data were collected from all training professionals of four ATI in Punjab with the help of structured questionnaire. Different questions related to demographic attributes, training needs and constraints faced by professionals affecting their performances. Collected data were analyzed with the help for SPSS, results revealed that majority of the were included training professionals did not get any training at national/ international level. Moreover, they were facing many constraints, which affect their performance like limited of financial resources and lack of linkage with research. The most emerging training needs were; recent development in agriculture, community development and mobilization, ICTs application in agriculture and designing of training with mean values of $2.84,2.82,2.74$, and 2.72 respectively. The government should provide training opportunities for professionals related to agriculture and training processes at national and international level.

Received | May 16, 2019; Accepted | September 1, 2020; Published | October 04, 2020

*Correspondence | Muhammad Yaseen, Department of Agricultural Extension, College of Agriculture, University of Sargodha, Pakistan; Email: yaseen99pk@hotmail.com

Citation | Yaseen, M., S.A.Z. Abid, M. Luqman, S.W. Hasan, M.A. Pitafi, M.T. Chaudhry and M. Ameen. 2020. Training needs assessment of training professionals working in agricultural training institutes in Punjab, Pakistan. Pakistan Journal of Agricultural Research, 33(4): 700-706. DOI | http://dx.doi.org/10.17582/journal.pjar/2020/33.4.700.706

Keywords | Capacity development, Training professional, Agricultural training institute, Training needs assessment

\section{Introduction}

$\mathrm{T}$ raining Needs Assessment (TNA) is an ongoing process to collect information related to needs being existed for any sort of training to improve performance of employees and to gain objectives of the institutions. Therefore, TNA is deemed to be most important segment in order to conduct required training successfully (Brown, 2002). TNA helps to evaluate competencies possessed by workers and to prioritize emerging needs to be focused during planning and conducting the training programs. That will also help to devise and formulate curriculum development for specific training program (Layfield and Dobbins, 2000). There are different dimensions of TNA for staff of any organization to assess their needs and to explore solutions to accomplish desired needs. Furthermore, TNA is also important to integrate science and technological advancement in agriculture sector (Cho, 2002). Sustainability of training needs is assessed through its ability to implement learning activities and incorporating in agricultural development (Chizari et al., 2006). Interestingly, the needs in training could also act as 
an advantage through the fact that the needs lead to sustainable solutions (Namdar et al., 2011).

Mostly trainings are criticized due to lack of TNA component, which plays significant role in successful completion and conduction of training (Roberson et al., 2003). It is globally perceived that competencebased trainings are rarely conducted, because effective and competence-based TNAs are not in practice (Tao et al., 2006). Training contributes greatly to the performance of employees and the organizations having good training plans for employees can upgrade the competencies of their workforce (Khan, 2012). Training professionals of various training institutes also faced challenges in adoption of emerging methodologies and improving professional competencies to deliver quality services (Myers et al., 2005).

The assessment of training needs leads towards sustainable solutions for issues and problems at farm level. Additionally, the needs also highlight weaknesses of training professionals, which could be changed into strengths by providing training (Black, 2014). The training needs could be assessed using observations, interviews and questionnaires methods for the purpose of professional development and enhancement of competencies (Sorensen et al., 2014). The integration of the competency and training needs are crucial for staff development with in institutions. Moreover, increased needs over time act as hindrances to the promotion of professional competencies (Okeowo, 2015). As a matter of fact, trainers and instructors have focused on initiatives that would promote competence levels of field staff (Davis and Jayaratne, 2015).

Evaluating training needs is helpful to identify needs and to improve competencies of professionals (Akers et al., 2004). Needs assessment provides long-term solutions to issues of staff to increase their efficiency (Washburn et al., 2001). Comparing ranks of different competencies possessed and needed by staff act as significant landmark towards TNA (Joerger, 2002). Traditional and advanced instructional modes are key factors to improve training methodologies. TNA helps to improve competencies as well training modes (Roberts and Dyer, 2004). Trainers' preparedness and competence is reflected on the performance of the training events conducted. There is a direct relationship between competence and the contents of the training program. Well-prepared training professionals demonstrate higher level of competency and ability to be imparted to participants. Furthermore, integration of technology, innovative training methodologies, and participants with special needs enhance the development of professional skills (Ricketts et al., 2005).

In most cases, the technological development has resulted to increase need for the professional trainers to verse themselves well with the enlarged scope. Therefore, it is prerequisite to equip training professionals with advanced methodologies, learning approaches, which can be fulfilled by assessing training needs of professionals and providing them training opportunities to improve their skills (Washburn et al., 2010). Extension field staff (EFS) has capacity building needs such as the ability to make certain decisions. In this way, EFS use the needs to formulate solutions in long-term sustainability. An integration of the challenges encountered by EFS is used as objective and management framework (Khan et al., 2011). In the same way, institutions perceive their structures as competent and competitive in different ways. All staff members should be given equal opportunities to avail trainings in their desired disciplines as prioritized through TNA. Imposing resilience in learning and teaching during training for agriculture professional is considered on of the best approaches to cope with the emerging challenges of current era (Thieman et al., 2012). The sustainability has a positive relationship with the improvements in training management. Sustainability in training would require inclusive measures focused on the levels of trainers' competencies (Alibaygi and Zarafshani, 2008).

The present study was designed to investigate various demographic attributes of training professionals, to assess various training needs of professionals and to find out constraints hindering the performance of training professionals.

\section{Materials and Methods}

Present study was designed to investigate needs of training professionals working in agriculture training institutes of Punjab province, which were In-service Agricultural Training Institute (IATI) Sargodha, Rahim Yar Khan, Barani Agricultural Training Institute (BATI), Rawalpindi and Agricultural 
Training Institute (ATI) Karor, Layyah. The training professionals of the institutes were engaged in conducting and imparting trainings for field staff of extension wing of agriculture department.

Professional trainers of the institutes were designated as instructors, senior instructors, deputy directors (training) and directors of agriculture/ principals in ascending order. All the training professionals were considered as sample for the study. A validated questionnaire was constructed as instrument of the study. Questionnaire was comprised of various sections including demographic characteristics (age, education, designation, experience, and national and international training received) needs of training professional relating to emerging issues in agriculture and constraints hindering their working performance. Questions relating to needs and constraints were asked using likert-type scales ranging 1=Less needed, $2=$ Moderately needed, $3=$ Strongly needed and $1=$ Not at all constraint, $2=$ Minor constraint, $3=$ Moderate constraint, $4=$ Serious constraint. Data were collected approaching deputy directors/ instructors of concerned training institutes. Collected data were analyzed using SPSS for descriptive statistics.

\section{Results and Discussions}

\section{Demographic attributes}

Demographic attributes have significant impact on the development of any society regardless of its nature of rural or urban. Development is also attributed with demography of any particular area. Considering the importance of demographic attributes, the respondents were asked about various demographic attributes. Which are discussed below:

Table 1 shows the majority (34\%) of training professionals working in ATIs was up to 30 years old and the percentage of the professionals that was above 50 years old was 32 while between the category $21-40$ was 26 whereas only $8 \%$ of the professionals was between the category $41-50$.

Table 2 reveals that majority (92.0\%) of respondents had master level degree (M.Sc. Hons.) in Agriculture, while only $8.0 \%$ of respondents hold Ph.D. degree in various disciplines of agriculture are working in these ATIs. Table 2 also shows that $11 \%$ respondents were with agronomy major while $10 \%$ were with horticulture, $8 \%$ were with agri. extension and $7 \%$ were with entomology major. For both of soil science and agricultural economics major were $4 \%$ and agricultural engineering, plant pathology and plant breeding and genetics were $2 \%$ for each major.

\section{Table 1: Age of training professionals.}

$\begin{array}{lll}\text { Age category } & \text { Frequency } & \mathbf{\%} \\ \leq 30 \text { years } & 17 & 34 \\ 21-40 \text { years } & 13 & 26 \\ 41-50 \text { years } & 4 & 8 \\ >50 \text { years } & 16 & 32\end{array}$

Table 2: Educational level and major subject of the training professionals.

$\begin{array}{llll}\text { Specialization } & \text { M.Sc. (Hons.) } & \text { PhD } & \text { Total } \\ \text { Entomology } & 6 & 1 & 7 \\ \text { Agri. extension } & 7 & 1 & 8 \\ \text { Agronomy } & 10 & 1 & 11 \\ \text { Soil science } & 4 & 0 & 4 \\ \text { Agri. economics } & 4 & 0 & 4 \\ \text { Horticulture } & 9 & 1 & 10 \\ \text { Agricultural engineering } & 2 & 0 & 2 \\ \text { Plant pathology } & 2 & 0 & 2 \\ \text { Plant breeding and genetics } & 2 & 0 & 2 \\ \text { Percentage } & 92.0 & 8.0 & 100.0\end{array}$

Table 3: Working titles of training professionals of ATIs.

$\begin{array}{llllll}\text { Institutes } & \begin{array}{l}\text { IATI } \\ \text { Rahim Yar } \\ \text { Khan }\end{array} & \begin{array}{l}\text { IATI } \\ \text { Sar- } \\ \text { godha }\end{array} & \begin{array}{l}\text { BATI } \\ \text { Rawal- }\end{array} & \begin{array}{l}\text { ATI } \\ \text { pindi }\end{array} & \begin{array}{l}\text { Karor, } \\ \text { Layyah }\end{array} \\ \begin{array}{l}\text { Director of } \\ \text { agriculture }\end{array} & 1 & 1 & 1 & 1 & 4 \\ \begin{array}{l}\text { Deputy director } \\ \text { of Agri. }\end{array} & 3 & 5 & 1 & 1 & 10 \\ \begin{array}{l}\text { Senior instructor } \\ \text { Instructor }\end{array} & 7 & 3 & 2 & 1 & 10 \\ \begin{array}{l}\text { Total } \\ \text { Total }\end{array} & 15 & 17 & 10 & 8 & 50\end{array}$

Table 3 illustrates the distribution of the respondents according to their titles/ designations in each Agricultural Training Institute. Each Agricultural Training Institute had one director while there were five Deputy Directors in IATI Sargodha, 3 deputy directors in IATI Rahim Yar Khan and the remaining two institutes had same number of Deputy Directors, which was one. There were four Senior Instructors in IATI Rahim Yar Khan, three in IATI Sargodha, two in BATI Rawalpindi and one in ATI Karor, Layyah. There were eight Instructors in IATI Sargodha, seven 
in IATI Rahim Yar khan, six in BATI Rawalpindi and five in ATI Karor, Layyah. The total number of Directors in all four ATIs was four, Deputy Directors were ten, Senior Instructors were also ten and the total number of Instructors was twenty-six. The total number of instructional staff in IATI Sargodha was seventeen while in IATI Rahim Yar Khan it was fifteen, ten in BATI Rawalpindi and eight in ATI Karoor, District Layyah.

The Table 4 depicts that institute experience and field experience of the training professionals working in ATIs. As the data was collected from the professionals working in ATIs so all the respondents had experience in institute but 26 respondents had no field experience and their percentage was 52 . The number of respondents was same who had 11-15 and 16-20 years of experience in institute and in field with frequency 4 and 1 respectively. The frequency of the respondents who had above 20 years of institute experience was 7 with percentage 15 whereas it was 5 with percentage 10 for field experience.

\section{Table 4: Experience of respondents.}

\begin{tabular}{lllll} 
No. of years & \multicolumn{2}{c}{ Institute experience } & \multicolumn{2}{c}{ Field experience } \\
& Frequency & $\%$ & Frequency & $\%$ \\
No experience & 0 & 0 & 26 & 52 \\
$\leq 5$ & 27 & 54 & 13 & 26 \\
$6-10$ & 8 & 16 & 4 & 8 \\
$11-15$ & 4 & 8 & 1 & 2 \\
$16-20$ & 4 & 8 & 1 & 2 \\
$>20$ & 7 & 15 & 5 & 10
\end{tabular}

National and international trainings received by the training professionals

National and international trainings play a significant role in enhancing the competencies of the training professionals to get knowledge about national and international level developments in agriculture and to get knowledge regarding innovative and advanced technologies in other countries. The national and international trainings received in 2016 and 2017 by training professionals are given in Table 5.

The following Table 5 shows number of trainings received by respondents during 2016-17. During year 2016, no training was taken by 23 , which were (46.0\%) among the instructors working in ATIs. While during 2017, 20 instructors did not receive any training contributing (34.0\%). The instructors who participated in only single national training program were (34.0\%) in 2016 and (48.0\%) in 2017. Instructors who participated in two national trainings were 18\% in 2016 and in 2017 they were (12.0\%) while only (2.0\%) instructors took trainings in 2016 and none of the instructors took training in 2017. In 2017 none of the instructors got national training and only (12.0\%) of the instructors received international trainings. It can be concluded from the results given in Table 5 that only few instructors got national and international trainings so the training system for the instructors is weak.

\begin{tabular}{|c|c|c|c|c|}
\hline \multirow[t]{2}{*}{ Trainings } & \multicolumn{2}{|l|}{2016} & \multicolumn{2}{|l|}{2017} \\
\hline & National & International & National & International \\
\hline 0 & $46 \%$ & $100 \%$ & $40 \%$ & $88 \%$ \\
\hline 1 & $34 \%$ & $0 \%$ & $48 \%$ & $12 \%$ \\
\hline 2 & $18 \%$ & $0 \%$ & $12 \%$ & $0 \%$ \\
\hline 3 & $2 \%$ & $0 \%$ & $0 \%$ & $0 \%$ \\
\hline
\end{tabular}

\section{Training needs of the training professionals}

Assessing the training needs of the professionals working in ATIs is imperative to develop competencies of professionals to achieve organizational goals. Training needs of professionals working in ATIs are given in Table 6.

Table 6: Training needs of the training professionals.

$\begin{array}{llll}\text { Training needs } & \text { Mean } & \begin{array}{c}\text { Std.de- } \\ \text { viation }\end{array} & \text { Rank } \\ \text { Recent development in agriculture } & 2.84 & 0.370 & 1 \\ \begin{array}{l}\text { Community development and mo- } \\ \text { bilization }\end{array} & 2.82 & 0.388 & 2 \\ \text { ICTs application in agriculture } & 2.74 & 0.443 & 3 \\ \text { Designing of training } & 2.72 & 0.454 & 4 \\ \text { Computer skills } & 2.58 & 0.575 & 5 \\ \text { Interpersonal skills } & 2.52 & 0.544 & 6 \\ \text { Instructional tools for trainings } & 2.42 & 0.609 & 7 \\ \text { Teaching methodologies } & 2.36 & 0.663 & 8\end{array}$

The data presented regarding the training needs of the instructors in Table 6 depicted that training need in present development in agriculture was ranked at $1^{\text {st }}$ with mean of 2.84 while training need in community development and mobilization was ranked at $2^{\text {nd }}$ with mean value of 2.82. Training need in ICTs application was ranked at $3^{\text {rd }}$ with mean value of 2.74 while training need in designing of training was ranked 
at $4^{\text {th }}$ with mean value of 2.72 and training need in computer skills was ranked at $5^{\text {th }}$ with mean value of 2.58 whereas training need in interpersonal skills was ranked at $6^{\text {th }}$ with mean value of 2.52 . Training need in instructional tools was ranked at $7^{\text {th }}$ with mean value of 2.42 while training need in teaching methodologies was ranked at $8^{\text {th }}$ with mean value of 2.36 .

Constraints bindering performance of the training professionals

The identification of the various needs facilitates to eliminate hindrances and helps to impart knowledge based competencies to professional of organization (King et al., 2013). The constraints affecting the competencies of the training professionals working in ATIs is given in Table 7 .

Table 7: Constraints bindering performance of the training professionals.

$\begin{array}{llll}\text { Constraints } & \begin{array}{c}\text { Mean } \\ \text { Std. de- Rank } \\ \text { viation }\end{array} \\ \text { Financial resources } & 2.92 & 1.576 & 1 \\ \text { Linkage with research } & 2.78 & 0.910 & 2 \\ \text { Linkage with farmers } & 2.62 & 0.901 & 3 \\ \text { Opportunities for seminars/workshops } & 2.62 & 0.987 & 4 \\ \text { Access to electronic media } & 2.52 & 0.839 & 5 \\ \text { Linkage with extension } & 2.50 & 0.931 & 6 \\ \text { Internet facilities } & 2.32 & 1.019 & 7 \\ \text { Transport facilities } & 2.28 & 0.858 & 8 \\ \text { Access to printed literature } & 2.28 & 0.784 & 9 \\ \text { Instructional resources availability } & 2.20 & 0.926 & 10 \\ \text { Computer facilities } & 2.12 & 1.003 & 11 \\ \text { Practical work facilities } & 2.10 & 0.974 & 12 \\ \text { Infrastructure facilities } & 1.92 & 0.944 & 13\end{array}$

The data regarding the constraint hindering the performance of the instructors presented in Table 7 show that constraint in financial resources was ranked at $1^{\text {st }}$ with mean value of 2.92 and this finding is similar to Ikeoji et al. (2007) who concluded that poor funding make it difficult for the agriculture teachers to implement the different strategies agreed on in both curriculum and institutional structures. While constraint linkage with research was ranked at $2^{\text {nd }}$ with mean value of 2.78 and the constraint in linkage with farmers was ranked at $3^{\text {rd }}$ with mean value of 2.62 whereas a constraint in opportunities for seminars/workshops was ranked at $4^{\text {th }}$ with mean value of 2.62. Constraint in access to electronic media was ranked at $5^{\text {th }}$ with mean value of 2.52 while a constraint in linkage with extension was ranked at $6^{\text {th }}$ with mean value of 2.50 . Constraint in internet facilities was ranked at $7^{\text {th }}$ with mean value of 2.32 whilst constraint in transport facilities and constraints in access to printed literature were ranked at $8^{\text {th }}$ and $9^{\text {th }}$ respectively with mean value of 2.28 both. Constraint in instructional resources availability was ranked at $10^{\text {th }}$ with mean value 2.20 while constraint in computer facilities was ranked at $11^{\text {th }}$ with mean value of 2.12. Constraint in practical work facilities was ranked at $12^{\text {th }}$ with mean value of 2.10 whereas constraint in infrastructure facilities was ranked at $13^{\text {th }}$ with mean value of 1.92 .

\section{Conclusions and Recommendations}

The results illustrated that majority of the training professionals never received any national or international training and facing many problems, which affected their performance. There were many constraints faced by training professionals in ATIs, which affected their performances. The most prominent problems were lack of financial resources, poor linkage with farmer, extension and research. All the training professionals preferred to receive training regarding agriculture. They put the training regarding new technology at first priority. They were also interested to get training regarding community development and mobilization, ICT applications, design a training program, computer skills, interpersonal skills, instructional tools and teaching methodologies.

On the basis of results of the study following recommendations were drawn for consideration to fulfill the needs of training professional working in ATIs in Punjab province:

- The government should ensure national and international trainings opportunities for the training professionals working in ATIs so that they can deliver trainings to extension field staff effectively.

- Training professionals should be rotated to perform field activities to be engaged with farming community. So that training professionals be aware about the problems of farmers. That will enable professionals to have diversified experiences.

- Government should arrange trainings for professionals especially in recent developments 
in agriculture, community development and mobilization, ICTs application in agriculture and designing of training programs, which are highly demanded, by professionals.

\section{Novelty Statement}

Current research work beholds the distinction of assessing the needs of Training Professionals working under the prime umbrella of Punjab Agriculture Department, Pakistan, and responsible for imparting training to Extension Field Staff (EFS) for enhancing their capacities to meet the ever-growing challenges of the current era of Sustainable Development. This manuscript has produced the roadmap for productively leading the training professionals through effective Human Resource Development strategies.

\section{Author's Contribution}

Muhammad Yaseen conceived the basic idea of research and principal author and designed research instrument. Syed Amir Zia Abid reviewed relevant literature and collected data. Muhammad Luqman edited draft paper and prepared final draft of paper. Syed Wasim Hasan edited research instrument and review of literature. Muhammad Aqeel Pitafi field data collection. Muhammad Tariq Chaudhry field data collection and data analysis. Muhammad Ameen prepared initial draft of research instrument and helped in data analysis.

\section{Conflict of interest}

The authors have declared no conflict of interest.

\section{References}

Akers, C., K. Miller, S.D. Fraze and J.D. Haygood. 2004. A tri-state needs assessment of emotional intelligence in agricultural education. J. Agric. Educ., 45(1): 86-94. https://doi.org/10.5032/ jae.2004.01086

Alibaygi,A. and K.Zarafshani.2008. Training needs of Iranian extension agents about sustainability: The use of Borichs need assessment model. Afr. J. Agric. Res., 3(10): 681-687.

Black, M.K., 2014. Perceptions of agricultural extension agents inservice training needs within the national agency for rural development in the Republic of Moldova (Doctoral dissertation, Texas $A$ and $M$ University). Retrieved from https://dspacepre1.library.tamu.edu/ handle/1969.1/153221

Brown, J., 2002. Training needs assessment: a must for developing an effective training program. Public Personnel Manage., 31(4): 569-578. https://doi.org/10.1177/009102600203100412

Chizari, M., A.H.A. Baygi and D. Breazeale. 2006. Analysis of the training needs of multifunctional extension agents associated with sustainability.J.Int.Agric. Ext.Educ., 13(1): 5158. https://doi.org/10.5191/jiaee.2006.13105

Cho, K.M., 2002. Training needs of agricultural extension agents in Myanmar. Proc. $18^{\text {th }}$ Ann. Conf. Assoc. Int. Agric. Ext. Educ. (AIAEE), Durban, South Afr., pp. 72-80.

Davis, R.J. and K.S.U. Jayaratne. 2015. Inservice training needs of agriculture teachers for preparing them to be effective in the $21^{\text {st }}$ century. J. Agric. Educ., 56(4): 47-58. https:// doi.org/10.5032/jae.2015.04047

Ikeoji, C.N., C.C. Agwubike and J.O. Disi. 2007. Perceptions of head agricultural science teachers regarding problems and challenges of vocational agriculture delivery in secondary schools in Delta State, Nigeria. Electron. J. Sci. Educ., 11(2): 6-17.

Joerger, R.M., 2002. A comparison of the inservice education needs of two cohorts of beginning Minnesota agricultural education teachers. J. Agric. Educ., 43(3): 11-24. https:// doi.org/10.5032/jae.2002.03011

Khan, M., 2012. The impact of training and motivation on performance of employees. https://ssrn.com/abstract $=2206854$

Khan, M.Z., Z.U. Haq, N.U., Khan, U. Pervez and M.A. Khan.2011. Training needs of agricultural extension agents in Khyber Pakhtunkhwa. Sarhad J. Agric., 27(1): 133-137.

King, D.L., K.L. Rucker and D.W. Duncan. 2013. Classroom instruction and FFA/SAE responsibilities creating the most stress for female teachers in the southeast.J. Agric. Educ., 54(4): 195-205. https://doi.org/10.5032/ jae.2013.04195

Layfield, K.D. and T.R. Dobbins. 2000. An assessment of South Carolina agriculture teachers' in-service needs and perceived competencies. Proc. 27 ${ }^{\text {th }}$ Ann. Natl. Agric. Educ. Res. Conf., pp. 572-584.

Myers, B.E., J.E. Dyer and S.G. Washburn. 2005. Problems facing beginning agriculture 
teachers. J. Agric. Educ., 46(3): 47. https://doi. org/10.5032/jae.2005.03047

Namdar, R., G.P. Rad and M. Chizari. 2011. An analysis of training needs of evaluation professionals of agricultural and extension programs in Iran. Afr. J. Bus. Manage., 5(21): 8585. https://doi.org/10.5897/AJBM11.1069

Okeowo, T.A., 2015. Analysis of competency and training needs among agricultural extension personnel in Lagos State. Int. J. For. Hortic., (IJFH), 1: 14-21.

Ricketts, J.C., D.W. Duncan, J.B. Peake and J. Uesseler. 2005. Teacher preparation and inservice needs associated with management of the total program of agricultural education in Georgia. J. South. Agric. Educ. Res., 55(1): 4659.

Roberson, L., C.T. Kulik and B. Pepper. 2003. Uning needs assessment to resolve controversies in diversity training design. Group Organ. Manage., 28(1): 148-174. https://doi. org/10.1177/1059601102250028

Roberts, T.G. and J.E. Dyer. 2004. Inservice needs of traditionally and alternatively certified agriculture teachers. J. Agric. Educ., 45: 57-70. https://doi.org/10.5032/jae.2004.04057

Sorensen, T.J., M.D. Lambert and A.J. McKim. 2014. Examining oregon agriculture teachers' professional development needs by career phase. J. Agric. Educ., 55(5): 140-154. https:// doi.org/10.5032/jae.2014.05140

Tao, Y.H., C.R. Yeh and S.I. Sun. 2006. Improving training needs assessment processes via the internet: system design and qualitative study. Internet Res., 16(4): 427-449. https://doi. org/10.1108/10662240610690043

Thieman, E.B., A.L. Henry and T. Kitchel. 2012. Resilient agricultural educators: Taking stress to the next level. J. Agric. Educ., 53(1): 81-94. https://doi.org/10.5032/jae.2012.01081

Washburn, S.G. and B.E. Myers. 2010. Agriculture teacher perceptions of preparation to integrate science and their current use of inquiry-based learning. J. Agric. Educ., 51(1): 88. https://doi. org/10.5032/jae.2010.01088

Washburn, S.G., B.O. King, B.L. Garton and S.R. Harbstreit. 2001. A comparison of the professional development needs of Kansas and Missouri teachers of agriculture. Proc. $28^{\text {th }}$ Natl. Agric. Educ. Res. Conf., 28: 396-408. 